\title{
Rheumatoid synovial cells in culture produce a growth inhibitor
}

\author{
CAROL A. SMITH \\ From the Department of Medicine, Montefiore Hospital and Medical Center, Albert Einstein College of \\ Medicine, Bronx, New York 10467, USA
}

SUMMARY Cultures of synovial cells obtained at surgery from patients with rheumatoid arthritis produced a protein which inhibits the mitosis of normal rabbit and human synovial cells, and of human lung fibroblasts. This mitotic inhibitory effect can be transferred to rabbit synovial cells by intra-articular injection of the animals with rheumatoid synovial cell cultures.

Plotkin and Vaheri (1967) showed the presence of a protein growth inhibitor in human lung fibroblast cultures infected with rubella virus. This protein substance slowed the mitosis of normal, uninfected cells. It has therefore been postulated that the presence of this material in high titre in rubellainfected cells might account for the frequent retardation of growth in infants with the rubella syndrome.

Two observations on human synovial fibroblasts in serial subculture led to the study of these cells for the presence of a growth inhibitor. First, the cultured synovial cells from patients with rheumatoid arthritis have a slower growth rate and shortened life span compared with their nonrheumatoid controls (Smith and Hamerman, 1969). These changes have also been observed in the human lung cell cultures with chronic rubella virus infection. Second, the rheumatoid cells are resistant to infection with rubella and other viruses, perhaps because of increased hyaluronic acid synthesis which prevents viral penetration, or other metabolic alterations (Patterson et al., 1975; Clarris et al., 1974). It was of interest therefore to determine whether rheumatoid cells contained a growth inhibitor (GI) with characteristics similar to the inhibitor in rubellainfected fibroblasts. Four strains of rabbit synovial fibroblasts were also available for study.

\section{Materials and methods}

\section{CELL CULTURES}

The human rheumatoid (RSC) and nonrheumatoid (NSC) synovial cells were cultured as previously described (Smith, 1971). Rabbit cells were obtained from animals previously exposed to human rheumatoid or nonrheumatoid synovial cells by intraarticular injection followed by synovectomy 4 to 8 weeks later, as previously described in detail (Smith et al., 1974). In serial subculture the cells were identified as of rabbit origin by their distinctive morphology and by chromosome count. Several of these rabbit 'rheumatoid-exposed' synovial cell cultures have previously been found to show altered production of hyaluronic acid, slow growth rates, viral resistance, and nuclear changes (Smith and Hamerman, 1976). Three such cultures (from animals exposed to rheumatoid membranes from 3 different patients) and one nonrheumatoid-exposed control rabbit culture were therefore examined for the presence of GI. All cell cultures were grown and maintained in Dulbecco-modified Eagle's medium plus $10 \%$ newborn calf serum, heat-inactivated.

\section{PREPARATION OF LYSATES}

The cell lysates to be assayed for GI were obtained from $5 \times 10^{5} \mathrm{RSC}$ or NSC, since larger numbers of cells are not readily available. The cell strains assayed had undergone 3-11 culture passages. The cells were trypsinised, lysed in $1 \mathrm{ml}$ of culture medium by freeze-thawing three times, then centrifuged at $10000 \mathrm{rpm}(12000 \mathrm{~g})$ for 30 minutes. This crude extract was made up to the appropriate dilutions with fresh nutrient medium.

\section{ASSAYS OF GI ACTIVITY}

Growth inhibition by the cell lysates was measured on fresh normal rabbit synovial cells at first, because these cells have a rapid growth rate and were readily obtainable. Replicate plates were seeded on day 1 , with 50000 normal rabbit cells per plastic dish, $9.6 \mathrm{~cm}^{2}$. 6 hours later the medium was removed 
and lysates of the human RSC and NSC were added to the test plates at the dilutions indicated (usually $1: 10,1: 40$, and $1: 80$ ). One medium change was carried out after 3 days, at which time freshly diluted lysate was again added. Replicate test plates were trypsinised and counted by haemocytometer on days 4 and 7 (except where otherwise noted). When the rabbit cell lysates were tested the entire procedure was carried out as described for the human RSC and NSC, except that serial dilutions were not used.

On two separate occasions the assays were carried out using NSC and RSC as test cells, to determine whether the GI present in the RSC was also effective on the human cultures of both kinds. In order to determine whether the GI is a protein, a lysate of $2 \times 10^{6} \mathrm{RSC}$ was divided into four aliquots. One aliquot was digested with DNA-ase, a second with RNA-ase, a third with trypsin, and the fourth left untreated. They were then incubated upon the test cells in the usual way.

In additional experiments the lysates were added to the freshly plated rabbit cells and to WI-38 (human lung fibroblasts), with $0.5 \mu \mathrm{Ci}{ }^{3} \mathrm{H}$-thymidine per plate, for two purposes: to see whether mitotic inhibition was indeed the method of growth inhibition; and to determine whether the GI was effective on human lung fibroblasts as well as on rabbit synovial cells. After 72 hours' incubation with the labelled thymidine, cells were washed and lysed in DNA buffer (standard sodium citrate: $0.15 \mathrm{M}$ sodium chloride and sodium citrate). They were dialysed exhaustively in this buffer, and the remaining undialysable material counted in Bray's solution in a Packard liquid scintillation spectrometer. This material was assumed to be cellular DNA and was totally digestible with DNA-ase.

\section{Results}

In all cases the RSC lysates showed growth inhibition of the normal rabbit synovial cells, compared with the effect of NSC lysates (Table 1). Preliminary experiments showed that growth of cells receiving NSC lysates was not different from that of untreated control cultures. Therefore a figure of $100 \%$ growth could be assigned to each group of NSC-treated cells to calculate the enhanced GI activity of the RSC lysates. GI activity was not related to the number of passages undergone by the cell strains assayed.

Two separate experiments also showed that GI was active on the NSC to the same extent as on the rabbit synovial cells. The RSC usually show slower growth rates, so that very little activity was demonstrable on these cells when studied with lysates from other RSC cultures. It is not clear then whether or not the GI present in the RSC is or is not as effectioxe on other RSC as it appears to be on the NSC, the rabbit synovial cells, and the WI-38.

Table 2 gives results of experiments in duplica区, using the RSC-exposed rabbit synovial cells, aga⿳⺈⿴囗十 measuring growth inhibition on normal rabbit ceñs compared to the control lysate of an NSC-exposegd rabbit synovial cell culture. The RSC-exposed cedls also showed enhanced GI activity.

When a rheumatoid lysate was digested with DNA-ase, RNA-ase, and trypsin, only the trypsin digest showed loss of GI activity (Table 3). It the fore appears that the GI is a protein, as shown Plotkin and Vaheri (1967), for the cells chronicaty infected with rubella virus. As Table 4, shows, the inhibitor markedly decreased incorporation of labelled thymidine into cellular DNA, therefofe

Table 1 Effect of RSC lysate on normal rabbit synovial cells, as compared with NSC lysate

\begin{tabular}{|c|c|c|c|c|}
\hline \multirow[t]{2}{*}{ Lysate } & \multicolumn{3}{|c|}{ Inhibition at 3 dilutions (\%) } & \multirow{2}{*}{$\begin{array}{l}= \\
\overrightarrow{0} \\
\stackrel{0}{0}\end{array}$} \\
\hline & $1: 10$ & $1: 40$ & $1: 80$ & \\
\hline $\begin{array}{l}\text { NSC } \\
\text { RSC-66 } \\
\text { RSC-68 }\end{array}$ & $\begin{array}{r}0 \\
68 \\
23\end{array}$ & $\begin{array}{r}0 \\
58 \\
10\end{array}$ & $\begin{array}{r}0 \\
50 \\
0\end{array}$ & ఫ \\
\hline $\begin{array}{l}\text { MSC-71 } \\
\text { RSC-53 } \\
\text { RSC-56 }\end{array}$ & $\begin{array}{r}0 \\
13 \\
24\end{array}$ & $\begin{array}{l}0 \\
0 \\
6\end{array}$ & $\begin{array}{l}0 \\
0 \\
0\end{array}$ & 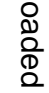 \\
\hline $\begin{array}{l}\text { NSC-112 } \\
\text { RSC-70 } \\
\text { RSC-43 }\end{array}$ & $\begin{array}{r}0 \\
41 \\
27\end{array}$ & $\begin{array}{r}0 \\
35 \\
22\end{array}$ & $\begin{array}{r}0 \\
18 \\
14\end{array}$ & $\begin{array}{l}\overrightarrow{\overline{0}} \\
\overline{3}\end{array}$ \\
\hline
\end{tabular}

NSC-99, RSC-66, etc. indicate the nonrheumatoid and rheumatoid culture numbers, each one derived from a different patient at surgery. Results were calculated 7 days after application of the lysates.

Table 2 Effect of RSC-exposed rabbit synovial cell lysates on normal rabbit synovial cells compared with NSC-exposed rabbit synovial cell lysate, 73-M

\begin{tabular}{llll}
\hline Cells & Cell count $\left(\times 10^{5}\right)$ & \multicolumn{2}{c}{ Inhibition } \\
\hline $73-\mathrm{M}$ & 3.4 & 0 & D \\
$73-\mathrm{N}$ & 2.4 & 30 & $\frac{\mathrm{O}}{\mathrm{O}}$ \\
$73-\mathrm{O}$ & 2.5 & 27 & $\mathrm{~N}$ \\
$73-\mathrm{P}$ & 2.6 & 24 & $\mathrm{~N}$
\end{tabular}

$73-\mathbf{N}, \mathbf{O}$, and $\mathbf{P}$ indicate $\mathbf{R S C}$-exposed lysates.

Table 3 Effect of digestion upon the growth-inhibiting factor in RSC lysate

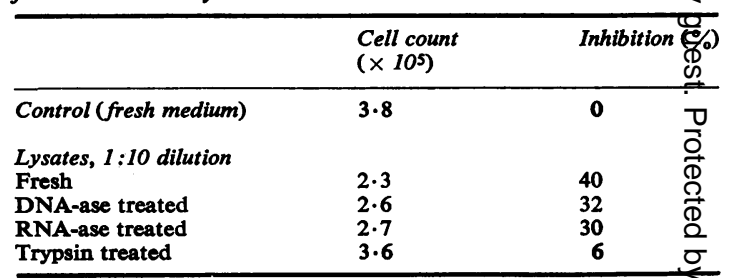


Table 4 Effect of growth inhibitor from RSC lysates on DNA synthesis in rabbit synovial cells, and in human lung fibroblasts (WI-38)

\begin{tabular}{llccc}
\hline Cultures & $\begin{array}{l}\text { Cell count } \\
(\times 105)\end{array}$ & $\begin{array}{l}\text { Inhibition } \\
(\%)\end{array}$ & $\begin{array}{l}3 \text { H-thymidine } \\
(\text { counts/5 min })\end{array}$ & $\begin{array}{l}\text { Inhibition } \\
(\%)\end{array}$ \\
\hline Normal rabbit cells + NSC-8 lysate & 8 & 0 & 1067 & 0 \\
Normal rabbit cells + RSC-1 lysate & $5 \cdot 2$ & 35 & 213 & 80 \\
& 1.5 & 0 & 10800 & 0 \\
WI-38 + NSC-15 lysate & 0.6 & 60 & 435 & 96 \\
WI-38 + RSC-3 lysate & & & \\
\hline
\end{tabular}

DNA synthesis is measured by 72 -hour uptake of ${ }^{3} \mathrm{H}$-thymidine, and by simultaneous cell counts on replicate plates.

slowing the mitosis of individual cells in the cultures. At the time these experiments were done the normal rabbit synovial cells available were freshly cultivated and were growing very rapidly, so that growth inhibition was readily apparent as 3 days. It was also apparent that the GI acted on human lung fibroblasts as well as on the cultured rabbit synovial cells (Table 4).

\section{Discussion}

These results indicate that our cultured human RSC do contain a trypsin-digestible material which inhibits cell mitosis. The growth inhibitor is effective on both rabbit synovial cells and human lung fibroblasts. This observation is of interest for several reasons. Since the cultured RSC have a slower growth rate and shorter life span than the NSC, it is possible that this GI substance is responsible for their altered behaviour in vitro. This is surprising in view of the finding in vivo that synovial cells of patients with rheumatoid arthritis showed marked proliferation within the inflamed membrane. However, the life span and growth rates of the cells in vivo cannot be measured in the human joint, so an in vivo GI effect cannot be studied. Castor (1971) reported a polypeptide designated connective tissue activating protein (CTAP) which was present in increased amounts in cultured RSC. CTAP added to NSC induced increased hyaluronic acid synthesis and made these cells less responsive to cortisol suppression of hyaluronic acid synthesis. It is not known whether our lysates also contain CTAP; it is possible that the same material which alters cell metabolism in terms of hyaluronic acid production also acts as a mitotic inhibitor.

The presence of GI in RSC is another manifestation of their altered metabolic activity in longterm culture and another 'trait' that can be transmitted to rabbit synovial cells by intra-articular injection of rabbits with RSC (Smith et al., 1974). Since infection with rubella virus induces production of a similar GI substance in WI 38 cells, it is possible that some occult virus infection is responsible for the presence of GI in the cultured RSC, and this finding may be further indirect evidence for a viral aetiology of rheumatoid arthritis. Such a virus-cell relationship need not be rubella, as many other viruses can also alter cellular functions during inapparent infections or incorporation into the cell genome.

This study was supported by grants from the US Public Health Service (AM 05082-08720) and the Research Corporation, Providence, R.I.

\section{References}

Castor, C. W. (1971). Connective tissue activation. II. Arthritis and Rheumatism, 14, 55-66.

Clarris, B. J., Fraser, J. R. E., and Rodd, S. J. (1974). Effect of cell-bound hyaluronic acid on infectivity of Newcastle disease virus for human synovial cells in vitro. Annals of the Rheumatic Diseases, 33, 240-242.

Patterson, R., Peterson, D., Deinhardt, F., and Howard, F. (1975). Rubella and rheumatoid arthritis: hyaluronic acid and susceptibility of cultured rheumatoid synovial cells to viruses. Proceedings of the Society for Experimental Biology and Medicine, 149, 594-598.

Plotkin, S. A., and Vaheri, A. (1967). Human fibroblasts infected with rubella virus produce a growth inhibitor. Science, 156, 659-671.

Smith, C. (1971). Properties of synovial cells in culture. Journal of Experimental Medicine, 134, 306s-312s.

Smith, C., and Hamerman, D. (1969). Significance of persistent differences between normal and rheumatoid synovial membrane cells in culture. Arthritis and Rheumatism, 12, 639-645.

Smith, C., and Hamerman, D. (1976). Evidence for a viral etiology of rheumatoid arthritis. Infection and Immunology in the Rheumatic Diseases, p. 213. Ed. by D. C. Dumonde. Blackwell, Oxford.

Smith, C., Hamerman, D., Janis, R., and Haberman, E. (1974). Virus resistance transferred from human rheumatoid cells to rabbit synovial cells. I. Methods and results of intra-articular injections of human cells into rabbit joints. II. Cell fusion. Annals of the Rheumatic Diseases, 33, 173-179; 180-184.

\section{Addendum}

B. J. Clarris et al. have also observed an inhibitory activity of rheumatoid cell extracts on homologous synovial fibroblasts. This work was reported at the XIV International Congress of Rheumatology, San Francisco, June 1977 (Abstract 194, p. 62). 